\title{
Culture and education as a binding condition for harmonious personal development
}

\author{
Viacheslav Sukhorukov*, and Yuriy Gladkiy \\ The Herzen State Pedagogical University of Russia, Moika Emb., 48, St. 191186 Petersburg, Russia
}

\begin{abstract}
The exclusive role of culture and education in the modern strategy of sustainable development is emphasized. For so many centuries, culture and education had a distinct flavor of luxury and were available, as a rule, to a select few. Currently, there is a widespread expansion of culture and education, and indicators of upbringing and training have become the primary condition for the sustainable existence of society and the individual. The question arises: what is the hidden primacy of culture and education today? The authors call the answer to it moral postulates and enlightenment, which affect not only the human mind, but feelings and soul, giving rise to desires and actions that obey the will. It is concluded that ideals, beliefs and other qualitative characteristics of a person are the main regulators of sustainable social life. Thus, the role of culture and education is to implement social harmony and ensure the quality of life of people.
\end{abstract}

\section{Introduction}

Culture as a set of ideas, values, traditions, norms of behavior, emotional reactions and other life attributes adopted by society is a person's identification mark. People think and act on the basis of culture, but they also subject it to their own influence and generate new cultural patterns. Therefore, culture is characterized by a deep historical character and endless diversity. All areas of natural and social life of a person, without exception, are permeated with cultural meaning.

Meanwhile, culture does not arise by itself, but is acquired through painstaking

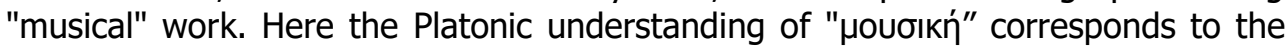
modern term "education" and implies a special intoned thinking. The main function of this way of thinking was to teach "to eurythmy and the tact of a separate human being in the general harmony of the world" [1; 2]. Already in antiquity, the inextricable link between culture and human mind was noted. It consisted in the ability to highlight the ordered symbols of the lived reality in the coordinates of space and time. These symbols were uncensored conscious attitudes, restrictions and rules that were dictated by specific conditions and circumstances. However, over the past epochs "musical art" gradually faded into the background and gave

\footnotetext{
*Corresponding author: suhor@herzen.spb.ru
} 
way to "intentional" consciousness, operating in the strict language of scientific categories [3].

It is believed that the current cultural world, in which people are constantly exposed to endless negative events, generates much more stress and fear than hope. Under such conditions, the human mind tends to be affective, and the results of practical actions only raise new fears that undermine positive intentions. As a result, people lose the ability to resolve acute and pressing social issues. A person begins to lose respect for himself, his appearance becomes anxious and tiring. To get out of this crisis state, first of all, a calmness of the mind is required, in order to provide the opportunity and inclination to the ultimate analysis and introspection. That is, "powerful peace is needed" as a stable arrangement of many human souls and human community $[2 ; 4]$.

The management of the spiritual sphere of the individual takes place through the education system, which reproduces culture and social relations that form a person's consciousness and his worldview. In turn, consciousness and worldview objectify the living world, affirming its values and the moral order of being. If a person remains freed from education and spiritual and moral development, he easily degrades to the level of a biological mechanism, losing his "obligation", dignity and inviolability. Therefore, the education of the population and its cultural level have become not only "mandatory", but also "binding" indicators of the quality of "human capital" and the potential of society in the implementation of strategic directions of development [5].

The actualization of the stated topic is largely justified by the rapid monetization of all spheres of creativity, which noticeably affects culture and education. The "decadence" that is more and more clearly manifested here, especially in Christian countries, is often caused by the absence of a coherent state ideology in the field of social development. Where the power of money prevails, ideas about patriotism, conscience and moral rules usually shift. Another reason for the decline of culture and education is globalization, leading to the displacement and destruction of many national achievements and values, deformation of civilizational identity. Another cause for alarm is associated with the growing anti-religious propaganda, as a result of which in many immature souls the criteria of good and evil, which for centuries have served as a moral guideline for believers and the general population, are suppressed.

The aim of this work is to strive to close the "distances" between culture, education and politics; humanitarian, natural science and technological views on society; theory, reality and practice of life. We believe that the obligatory prerequisite for the solution of these dispositions is to reboot a person with the semantic energy of balanced development.

\section{Materials and methods}

Over the past three centuries, the greatest contribution to the knowledge of culture has been made by such outstanding Russian thinkers as V. I. Dahl, N. Ya. Danilevsky, K. N. Leontyev, L. I. Mechnikov, N. A. Berdyaev, P. A. Sorokin, A. F. Losev, L. N. Gumilev, A. G. Dugin, etc. Following foreign scientists' are remarkable: I. Garder, L. Morgan, E. Dühring, G. Le Bon, E. Husserl, A. Weber, O. Spengler, K. Jaspers, A. Toynbee, M. Heidegger, S. Huntington, E. Toffler, F. Fukuyama et al. The works of these scientists and philosophers contain original views and concepts of a culturological nature, demonstrating the deep connections between culture, politics, economics, and social life. Their works are designed not only for professional understanding, but are available to a wide range of 
readers and are completely open. The literary materials and sources used in the article reflect the achieved level of understanding of the cultural subject $[1 ; 2 ; 4 ; 5 ; 7 ; 12 ; 13]$.

In the interpretation of education as an integral attribute of culture, the emphasis is placed on its value non-randomness (regularity), reflecting the objective causality of the surrounding world. In this sense, the dialectic of the modern pedagogical process cannot ignore the eternal problem of human quality. Not only the humanities, but all areas of knowledge must refer to the value recipes with which life itself was originally sewn. Therefore, the education has become a decisive factor in the sustainable development of society and a responsible political technology. Thus, culture and education are confidently turning into an imperative of a reasonable and moral Future of Humanity $[3 ; 6 ; 8-10 ; 11]$.

Synthetic thinking, which was required to achieve the goal set in the work, is the most difficult and difficult. Most often it is achieved at the level of empathic understanding of the subject of research. This means the indispensable use of methods for the qualitative description of the subject and a comprehensive interpretation of the originality of the object under study. This culture of scientific knowledge is called idiographic (The prefix "idio" comes from the Greek "special", "peculiar", "individual"). It was she who was chosen by the authors as the main methodological approach.

\section{Results and discussion}

\subsection{The immensity of culture}

Culture and man are fused in each other. Culture is woven into human life with virtually no limits. One way or another, culture encompasses all states of the life world. Therefore, the essence of culture is characterized by immense features and interpretations.

In everyday reality, both products of physical labor and works of a spiritual and intellectual nature are perceived as attributes of culture. Meanwhile, true culture is most often associated with outstanding achievements in certain areas of human life. In this sense, the term "cultured person" should refer to people who have assimilated the accumulated wealth of society to the maximum extent possible.

In relation to the entire dynamics of social life, the limiting characteristic of culture is the equivalent concept - civilization. This word refers to large-scale cultural formations, characterized by a mature state that generates the required conditions for an orderly and stable life. However, a strict and unambiguous definition of civilization, as well as culture, has not yet emerged. This is explained by the depth of the content of these terms, summarizing the entirety of the human world. Nevertheless, both concepts have managed to find a strong attachment to the ideals of prosperity and reliable stability, therefore they are perceived as a pseudonym for an attractive and comfortable life.

Given the close relationship between culture and civilization with issues of social practice, many researchers were inclined to measure the cultural state of a person by its proximity to the norms and prescriptions accepted in society. In this case, it turned out that "less cultured" people combined their cultural minimalism with a pronounced "naturalness". On the contrary, "highly cultured" individuals were forced to suppress their "human nature". However, over time, such views began to be rejected. Now, statements about a "higher" and "lower" culture or civilization, about their opposition to nature, are no longer accepted. In modern conditions, the 
parallelism and self-sufficiency of cultures and civilizations is recognized, but also the uniqueness of human "whoseness" as an indivisible singularity.

Ultimately, culture embodies the main format of human life in the space-time continuum. According to Dahl V.I., the way of reproduction of any culture is "processing", "care" and "cultivation". The leading mechanism of these manipulations remains mental and moral education, the essence of which lies in the "processing of people by people" and in the "processing of nature by people". Therefore, the more perfect these "treatments" are, the deeper the impact of culture on the masses and the individual will be. Such a "processed", "wellgroomed" and "cultivated" culture will necessarily become a "strategic culture" on which national security, the stability of the individual, society and power will ultimately depend.

\section{2 Education as an acquired capital}

Modern education symbolizes deep immersion in the knowledge of reality and its material nature. Understanding everything visible and comprehending what is happening was and remains the primary task of teaching. Herewith, education is responsible for the formation of ideas about ideal values, which, together with empirical knowledge and practice, make up a single human life world. Let us put it more precisely: it is on the value paradigm that the ideological formula of education is based, with the help of which the problem of reproduction and manifestation of the best examples of life experience is solved through the transmission of the whole picture of life in small plots.

Thus, in the content of education, an inextricable alliance of training and upbringing is firmly preserved. This union gave rise to a special pedagogical culture that combines objective categories with social postulates and value norms that reveal the purpose of a person. In this unity and endless dialogue, the feelings and mind of a person are formed, giving rise to self-consciousness of the individual and the moral order of being.

It is noteworthy that since the invention of the first mass schools, they began to engage in useful teaching pursuant to an "explicit" plan and herewith embody an "invisible" or "hidden curriculum" that was more solid. It was a special educational setting, and in the future, a program of a specific purpose [8].

The current "world didactics" also strives in the educational process to connect the principles of scientific rationality with humanistic, religious and ethical guidelines of human practice. In other words, it implies the professional "art of letting the conscious into the unconscious" [9]. This skill is at the heart of the educational process that ensures the ascent of a person to a mature and stable state in which he is most prepared and adapted to create benefits. Let us refer here to Plato. The classic argued that only education "in the end depends on a well-defined and expressed result: either good or its opposite" [1]. Note that the word "good" in the above quotation means not only something positive, but also ontological perfection as a required condition for sustainable existence.

Meanwhile, the education acquired by a person becomes a reliable good only in the process of self-affirmation of the human mind within the boundaries of the general and objective culture. Consequently, the opposite, that is, negative meaning, is lack of education, cultural ignorance and cultural nihilism, which still persist among people. It is regrettable that ignorance and ignorance may still be explained by specific gaps in the training system and try to smooth them out, but the mentioned nihilism is already fraught with a more serious threat. The danger 
lies in the human mindset that rejects culture and education as an acquired capital that meets the investment of time and labor, contributing to the accumulation of human wisdom and experience. Such "deniers" of culture and education are in a state of very serious ignorance, for lack of education, bad manners and rejection of the generally recognized so-and-so and filth, "that a person is not beautiful, and not perfect, and not smart is completely satisfied with himself" [10, p. 19]. This thought may be continued: ignorance, inability, lack of civil consciousness affect the life world at times on a much larger scale than all successful deeds.

It turns out that education is always aimed at establishing a lasting future, because knowledge is only promising. Thanks to the collective efforts of educated people, constant investments are made in the ecumene and the very configuration of the Earth. Hence, it follows that the thinking presence of a person in the inhabited space must be considered a fundamental circumstance of the entire world dasein (German dasein) as a present being. Herewith, the moral understanding of the world is insistent, which should not be subject to any doubt.

For this reason, education should be seen as a prerequisite for human life. The imperative nature of education gives it very flexible contours. The most obvious is formal education provided by educational organizations on the basis of specially designed programs. (In the current circumstances, formal education has even acquired a large-scale distance character). Non-formal education is also actively practiced, which may be carried out both in an educational institution and outside it. Such education may be very broad and include a large number of areas. Finally, informal education should be considered inevitable and the most deliberate for a person. It is often called everyday, since it means a conscious, but often unconscious cognition of a new one in an everyday environment. It is probably impossible to compile a complete list of types of informal education, because cognitive preferences and hobbies of people are purely individual. One way or another, everyday education is a voluntary subject and general cultural enhancement of a person without the participation of institutional structures [11]. Informal education ultimately becomes self-education, which, along with traditional forms of acquiring knowledge and value attitudes, generates the cultural matrix of humanity.

\subsection{Discussion}

The global world actively invades every human destiny. Under its influence is the culture and consciousness of a person, his work and leisure, politics and economics. These plexuses are becoming even more solid as a result of the unprecedented rapid spread of information, knowledge, values, tastes and perceptions prevailing in different societies. Some of the assimilated life attributes may remain without active movement, others may easily and quickly be grafted and expand the range of their action. As a result, a new "transcivilization" is confidently ascending over the existing societies, imposing its own way of life.

The changes that are made in the real world affect the personality ambiguously. Their impact may have both positive and negative signs. For example, the high-speed rhythm of everyday life, unprecedented information saturation and other satellites of modern civilization make the human psyche tense. In some cases, this stimulates creative activity, but more often high external pressure on a person causes stiffness, devastation and disorientation of the personality. Living space in such circumstances loses its stability. Therefore, the "human factor" in the specific conditions of current practice is becoming extremely topical and becomes an independent global problem. 
There are many versions explaining the "human problem" in the modern world. The following reasons for social instability are indicated - an unprecedentedly high dynamics of the living space, weakening the adaptive capabilities of the individual, environmental instability, humanitarian interventions, ideological provocations, political blackmail, bureaucratization of power, etc. Meanwhile, the problem of a person is not reduced to the influence of only external causes, for the personality should not be considered only a passive object of certain conditions and circumstances.

The essence of a person is determined not only by the social aspects of being, but mainly by his inner unique nature. A person in all cases of life remains a unique individual, in whose consciousness any constructs may fit. Herewith, a person is never deprived of freedom of thought and choice, preferring to think and act on the basis of convictions and obey only himself. Consequently, the reality surrounding a person acquires subjective characteristics inherent in human culture.

In times of rapid change, people face a particularly acute question of defining their identity. At such times, a "search" consciousness arises and an interest in moral problems, in questions of life values, meaning and purpose of being, sharpens. As a result, the world turns into an experienced value that generates a new consciousness. Herewith, axiological attitudes make it possible to construct such structures of a given reality, which for a particular person acquire the meaning of an ideal object.

It is noteworthy that the "developers" of the coming world do not disregard the issue of the so-called "posthuman". The content of the proposed anthropological views is that an individual ("indivisible") may turn into a dividual ("divisible"). They argue that the parts of a single person have some autonomy and are not only in harmony, but tend to contradict each other. Obvious conflicts are seen here between the body and thinking, desires and reason, consciousness and subconsciousness. (It turns out that a person is able to have a clear head and a subtle mind, in no way connected with bodily life and spiritual order?) It is from here arise the sonorous concepts of "dismemberment" of the future person - "Body without organs" (A.Artaud, G. Deleuze), "Risoma" (G. Deleuze, F. Guattarl), "Cyborg" (D. Haraway), "Posthuman conditions (R. Pepperel) etc. [12].

However, whatever the next cultural and historical period turns out to be, all the achievements of civilization and grandiose long-term plans reveal the dangerous pride of modern mankind. This refers not only to the highest spiritual principles, but to the most natural picture as an inevitable circumstance of life. Nature has been and will forever remain the primary condition for human well-being, providing for their basic needs. In addition to the obvious to all instrumental function, nature is an imperative of the bodily and spiritual strength of man, from which his self-awareness comes. That is, nature still commands a person in the same way as thousands of years ago disposed of the affairs and destinies of our distant and defenseless ancestors. Therefore, politics should not forget that nature at all times retains the meaning of planetary universality and determination [13, p. 122]. This means that the logic of a sustainable world order must be based on the principle of balance of the natural, intellectual, spiritual and volitional forces of society. It is in this case that culture and education enable a person to live with dignity.

\section{Conclusions}

1.Culture and education are a decisive factor in the sustainable development of society. Culture and education embody the social matrix of the world of life, in the center of which is not the physical individual, but the "humanity of man." A person 
who is outside culture and education revolves only around himself, losing the ability for productive creativity.

2.The stability of the society is given by the system of intellectual, moral and spiritual values. The mechanism for the transfer of accumulated public goods and life experience from generation to generation remains education, upbringing and harmonious development of a person. Therefore, culture and education have become an obligatory condition of modern life and acquired an imperative character. The main command of culture and education is the development of thinking and the formation of the spiritual and moral content of a person, which determine the meanings and directions of individual life and social strategy.

3.The main reliable wealth of society was and remains the harmonious development of the individual. Modern man has reached deep rootedness in the surrounding space and the present world has turned into his active projection. The indicated similarity between man and the world he created testifies to their indissoluble unity and inexhaustible vitality of the individual.

\section{References}

1. Plato. State., 53, 68, 120 (2016)

2. A. Toporova, Personal development, 1, 161 (2014)

3. E. Husserl, Logical investigations: Investigations in Phenomenology and Knowledge (2011)

4. P. A. Nikolaev, Culture as factor of national security of Russia, https://poisk-ru.ru

5. Yu. Gladkiy, V. Sukhorukov, A. Chistobaev, Human Capital and the Sphere of Values in the Conditions of Innovative Economy, 1(47), 1334 (2019)

6. V. Sukhorukov, Yu. Gladkiy, ICPCS 2019, Series: Advances in Social Science, Education and Humanities Research, 315, 90 (2019)

7. A. V. Kostina, E. F. Makarevich, O. I. Karpukhin, V. A. Lukov, Culture as factor of national security of modern Russia: Value and role model, 12 (2021)

8. E. Toffler, The Third Wave, 65 (1999)

9. G. Le Bon, Psychologie de l'éducation, https://ru.wikipedia.org

10. Plato, Symposium, https://iknigi.net/avtor-platon

11. V. P. Dronov, Geography and ecology at school of the 21 st century, 9, 23 (2016)

12. A. Dugin, Ethnosociology, 490 (2014)

13. Yu. N. Gladky, V.D. Sukhorukov, Bulletin of RAS. Geographic series, 5, 121 (2019) 